\title{
Motives and tensions in the release of open educational resources: The UKOER program
}

\author{
Isobel Falconer \\ University of St Andrews, UK
}

\author{
Allison Littlejohn \\ Open University, UK
}

\section{Lou McGill}

Independent consultant

\section{Helen Beetham \\ Independent consultant}

\begin{abstract}
Open educational resources (OER) have been promoted as a path to universal education, supporting economic development and intercultural dialogue. However, to realise these benefits requires greater understanding of the factors that influence both OER supply and use. This paper examines an aspect of the supply side of the OER lifecycle - the motives prompting release - and the resultant tensions in the release process. It draws evidence from a major program of OER release projects (UKOER) funded by the UK government. The paper sets the UKOER program within the global context of OER initiatives. It uses grounded theory to identify five candidate motive types. Then, by mapping the actions evident in the UKOER program against an organisational framework derived from an activity system, it examines tensions or contradictions encountered by the projects, revealing unstated motives. The findings will be of interest to funders, institutions and educators releasing OER as they reveal potential limitations and barriers to realising the benefits of OER.
\end{abstract}

\section{Introduction}

In recent years, efforts to ensure universal access to high quality education have been viewed as a prime way of promoting sustainable social and economic development, and intercultural dialogue (Bossu, Bull, \& Brown, 2012; Europa, 2009; UNESCO, 2012). At the same time, individual nations, and economic groupings such as the European Union, are calling for a fundamental transformation of education to develop new competences among their citizens if they are to remain competitive (Barroso, 2012; European Commission, 2013; Kanwar, Kodhandaraman, \& Umar, 2010). Since their inception in 2001 with MIT's Open Courseware initiative (Livingstone-Vale \& Long, 2003), the potential for open educational resources (OER) to play a major role in realising these ambitions has been mooted. The Organisation for Economic Co-operation and Development (OECD) concluded in 2007 that the idea of "giving knowledge away for free had made considerable progress" and advocated greater efforts to boost OER in order to improve global access (OECD, 2007), while UNESCO (2012) views OER as providing, "a strategic opportunity to improve the quality of education as well as facilitate policy dialogue, knowledge sharing and capacity building" (UNESCO, 2012). By 2011 Bossu and Tynan (2011) concluded that, “OER are here to stay” (p. 259). Individual countries have responded by promoting OER through centres such as the Australian DEHub (DEHub, 2012), or government strategies and policies as in Poland, New Zealand or Brazil (DmochowskiLipski, 2014; New Zealand Government, 2010; Rossini, Sebriam, Gonsales, \& Santana, 2011). International organisations such as UNESCO, OECD, and ICDE are working collaboratively through projects such as the Open Educational Quality Initiative (OPAL) to raise the profile of OER (OPAL, 2016).

However, while OER are high on the agenda of educational policy makers, OER release and use is still not a widespread practice. This is despite the potential benefits, such as encouraging innovation, promoting the concept of lifelong learning, enhancing the quality and flexibility of resources, and showcasing the institution being widely articulated (McGill, Falconer, Dempster, Littlejohn, \& Beetham, 2013; OECD, 2007; Willems \& Bossu, 2012; Yuan, MacNeil, \& Kraan, 2008). To realise the benefits requires a much better understanding than we have at present of the factors that influence the OER lifecycle, on the supply side as well as the usage side. Investigation of the reasons behind this slow uptake have tended to focus on 
barriers to use. Technical, cultural and contextual barriers have all been cited (Bossu, Brown, \& Bull, 2014; Cooper, Lockyer, \& Brown, 2013; Panke, 2011). However, barriers to the release of OER have not been similarly investigated. While there is recognition that the release of OER in itself will not automatically lead to use by others (Lane \& MacAndrew, 2010; McGill, Beetham, Falconer \& Littlejohn, 2010), there is, nevertheless, felt to be a need to build up a critical mass of resources in order to promote use. However, the tensions inherent in the activity of OER release have not been extensively explored.

This paper aims to explore the supply side - release of OER, elucidating some of the tensions and the differing motives in which they originate. It does so in the context of the UK Joint Information Systems Committee (JISC) and Higher Education Academy (HEA) UKOER program. Through the associated evaluation and synthesis project (McGill et al., 2010) we collected data from 29 UKOER projects in the form of reports, blog postings and outputs. Using grounded theory we first identify and categorise the overarching motives of the program and its component projects. Then, by mapping the experiences of the projects against an organisational framework derived from an activity system, we identify tensions resulting from these motives. We conclude by discussing the tensions and their implications for embedding a culture of openness in education.

\section{The UKOER program in the context of OER initiatives}

In 2009-2010, JISC and the HEA, UK government agencies, funded a program of projects to release OER: the UKOER pilot program.

The OECD (2007) defines OER as, "digitised materials offered freely and openly for educators, students and self-learners to use and reuse for teaching, learning and research". The first major OER release project was MIT's OpenCourseWare initiative of 2001 (Livingstone-Vale \& Long, 2003), funded by the William and Flora Hewlett and the Andrew W. Mellon foundations. Since then a wide range of initiatives have produced resources that might be explicitly described as OER.

OER may be categorised by two dimensions - the resource type and the degree of openness. Atkins, Seely Brown, and Hammond (2007) identify five resource types around which OER programs cluster, distinguished by their aims to:

(1) Build capacity in developing countries for effective use of OER. Programs include the Teacher Education in Sub-Saharan Africa project (http://www.tessafrica.net/), the UNESCO virtual university (http://www.unesco.org/iiep/virtualuniversity/overview.php), and the OER Africa project (http://www.oerafrica.org/).

(2) Build a relevant research community. Projects focus on OER, their release and use as an object of enquiry. Examples include the Commonwealth of Learning program, which appoints honorary chairs to advance knowledge around OER (Commonwealth of Learning, 2014).

(3) Build awareness, voice, and understanding. Such projects include the Open Courseware Consortium (http://www.oeconsortium.org/), the Open Learning Network (http://www.olnet.org/), and The University of Canberra's "RecentChangesCamp2012" (RCC2012, 2012).

(4) Develop general software and middleware services infrastructure for creating, federating, and finding OER resources. These projects include the UK Open University OpenLearn Works (http://www.open.edu/openlearnworks/), the work of Macquarie University's e-learning centre of excellence (http://melcoe.mq.edu.au/), and the Learning Resource Metadata initiative (http://www.lrmi.net/).

(5) Incubate high quality specialized open resources. These are projects that publish digital material with or without provision for collaborative learning around the materials. High profile initiatives in this area are MIT OpenCourseWare (http://ocw.mit.edu/index.htm) and the OER University (http://oeru.org/).

The UKOER program initiated projects of the fifth type, aiming to develop and release open resources. The funding call highlighted five levels of resource with increasing degrees of embedded information (JISC, 2009a). In doing so it implicitly steered projects towards the type of resource identified by the OECD (2007) as "learning content", in other words, full courses, courseware, content modules, learning objects, collections, and journals. 
While taking a fairly narrow definition of "resource”, the program's definition of "open” as, "free for use and repurposing worldwide" (JISC, 2009b), with the specification that resources must be released under an open licence and deposited in a national repository, JorumOpen (JISC, 2009b) conformed largely with the Public Library of Science definition of “open” advocated in Downes (2007, p. 32):

- $\quad$ Free, immediate access online

- Unrestricted distribution and re-use

- $\quad$ Author retains rights to attribution

- $\quad$ Papers are deposited in a public online archive such as PubMed Central.

Thus, the position of the JISC UKOER program on the two dimensions of resource type (categorised by Atkins et al., 2007) and of characteristics of openness (Downes, 2007) is as summarised in Figure 1.

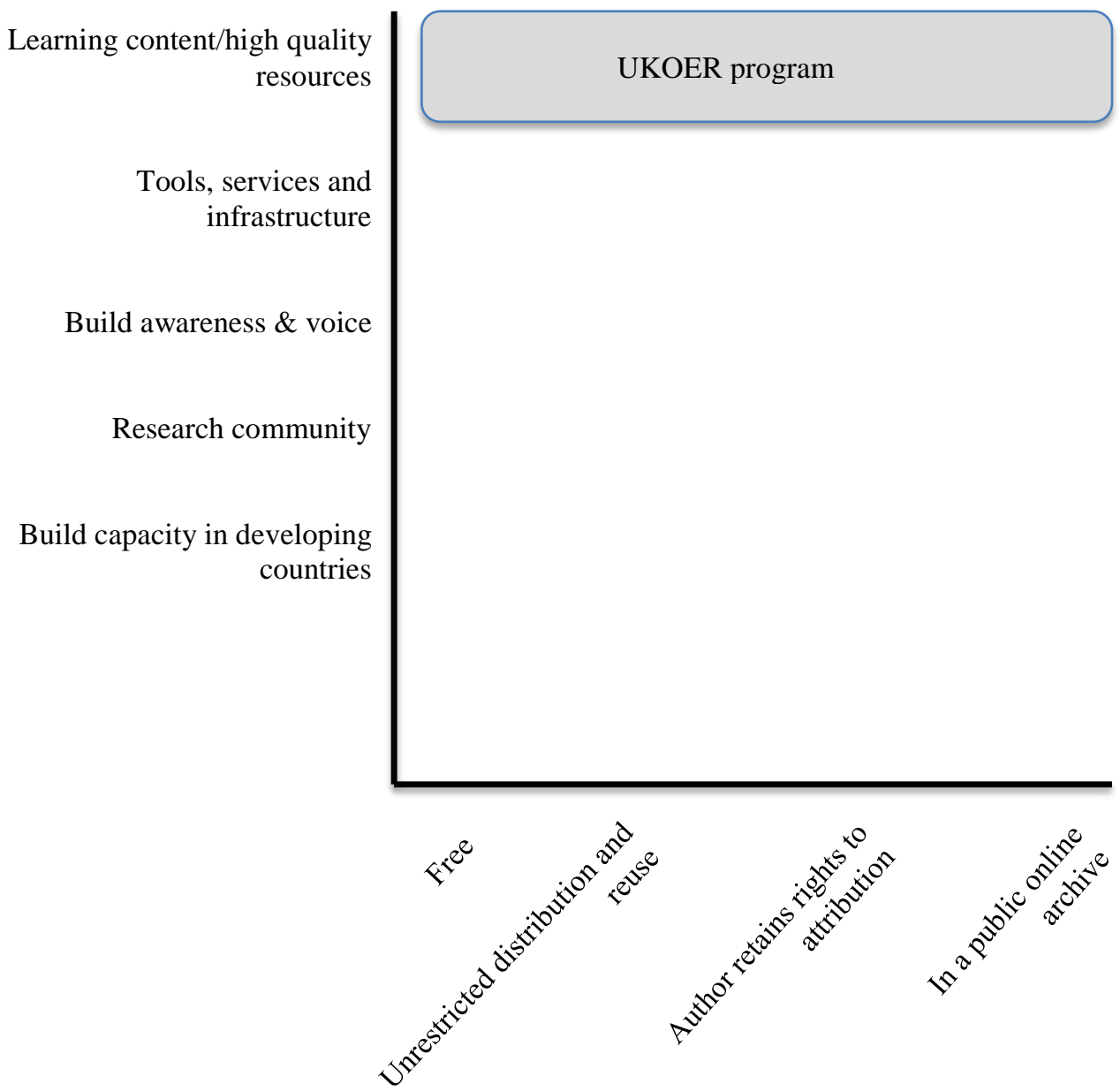

Figure 1. The position of the UKOER program on the two dimensions of characteristics of open, and of type of resource

Twenty-nine projects were funded at universities, colleges and HEA national subject centres distributed across England and Wales. Project teams were of three types: institutional, subject communities, or individuals. The program had a narrow focus on experience of release (rather than reuse) of OER. It operated on two basic premises: that widespread involvement of teaching staff would bring about a sustainable change in culture from focusing on content ownership, to focusing on open sharing; and that building a critical mass of OER would bring about sustainable change in practices of reuse and repurposing. Thousands of resources were made available under Creative Commons licences. However, it was impossible within the funded 1-year projects to evaluate whether either of the changes had achieved 
sustainability. The program did, however, encounter a number of tensions raised by the release process itself, that have implications for the embedding of a culture of openness and sharing that go beyond the narrow confines of the UKOER program. This paper aims to explore these.

\section{Methodology}

Identifying the overarching motives driving OER release is central to analysing the ways in which OER practice is changing. We took a two-stage approach to identifying motives and their associated tensions.

First, we used grounded theory to elucidate an initial list of candidate motives. In contrast to traditional social science research, grounded theory begins with data collection around the topic of interest (Glaser \& Strauss, 1967). The data is reviewed for repeated ideas or concepts, which are labelled with codes. The dataset is then expanded and the codes are re-reviewed in an ongoing iterative process until the set of codes is stable and further data does not reveal new necessary codes. Our topic of interest was the motives of the projects within the UKOER program. Our evidence came from statements in project plans, from a brainstorming activity held at an evaluation workshop for the program (McGill et al., 2010), and from the JISC calls for funding (JISC, 2009b). We identified common themes in the stated objectives and anticipated benefits from the plans and funding call, coding them into groups that appeared to correspond to similar overarching motives, either implicit or explicit. From this data we developed a typology of motives.

The outcomes are subject to the caveat that the authors of all three sources of evidence had a vested interest in funding for OER. Consequently, they may have used an element of rhetoric to appeal to funders. This means that the proposed benefits have to be treated with a degree of caution if they are interpreted as governing motives. Furthermore, we cannot take for granted that the benefits stated in the JISC (2009b) funding call were actually adopted as motives by the projects or the institutions within which they were based. The force of the latter point is shown by the fact that by 2009 few UK universities had adopted the benefits as motives even though the "Good Intentions" report (McGill, Currier, Duncan, \& Douglas, 2008) the previous year had evidenced them in some detail.

The typology was then tested in two ways. First, it was mapped against motives suggested elsewhere in the literature (Atkins et al., 2007; Cape Town Declaration, 2008; Downes, 2007; OER Africa, 2013). More tentatively, the motive clusters were grouped into those that appeared to uphold similar higher-level values.

In the second stage of analysis, the typology was tested against the motives revealed by the actions and tensions experienced in the UKOER projects. As Edwards (2010) has pointed out, even where motives are not stated explicitly, they are revealed by actions. Evidence of actions and tensions came from our UKOER program-wide synthesis and evaluation which used project reports, blogs, and workshop discussions to explore common issues around the release of OER; and cultural differences across the sector in the norms, rules and reward structures surrounding OER practices (McGill et al., 2010). Where we found tensions, we investigated whether our typology of motives was sufficient to explain their origin.

The relationship between motives and tensions is a feature of activity theory. Activity theory sees human activities as complex, socially situated phenomena. Rather than being a predictive theory, it provides a descriptive framework for describing and analysing the relationship between actions and other components of the socio-techno-cultural situation (Center for Activity Theory and Developmental Work Research, 2004). These components and relationships are typically represented in a triangular activity system (Engeström, 1987) which represents the situation in which community members (subjects) work on some sort of object or problem space, transforming it into an outcome using tools which may be technological (such as software) or conceptual (such as pedagogic theory). The tool-mediated action may be constrained or enabled by implicit and explicit rules and the broader social context (community) within which the activity takes place. Labour is divided among the community members (roles). In this paper we take the project teams as subjects and the release of specific OER as the object of the activity; an activity triangle for one of the UKOER projects is shown in Figure 2.

A premise of activity theory is that activities are outcome-oriented, and driven by project goals and motives. Leontiev (1981) describes three levels of human activity (activities, actions, operations), with the highest level (activity) governed by motive. The motive sits above the system, defining the problem space or object 
being worked on and giving the activity “directionality, purpose, and meaning” (Engeström, 2005, p. 312). The object of the activity provides a focus for the overarching motive.

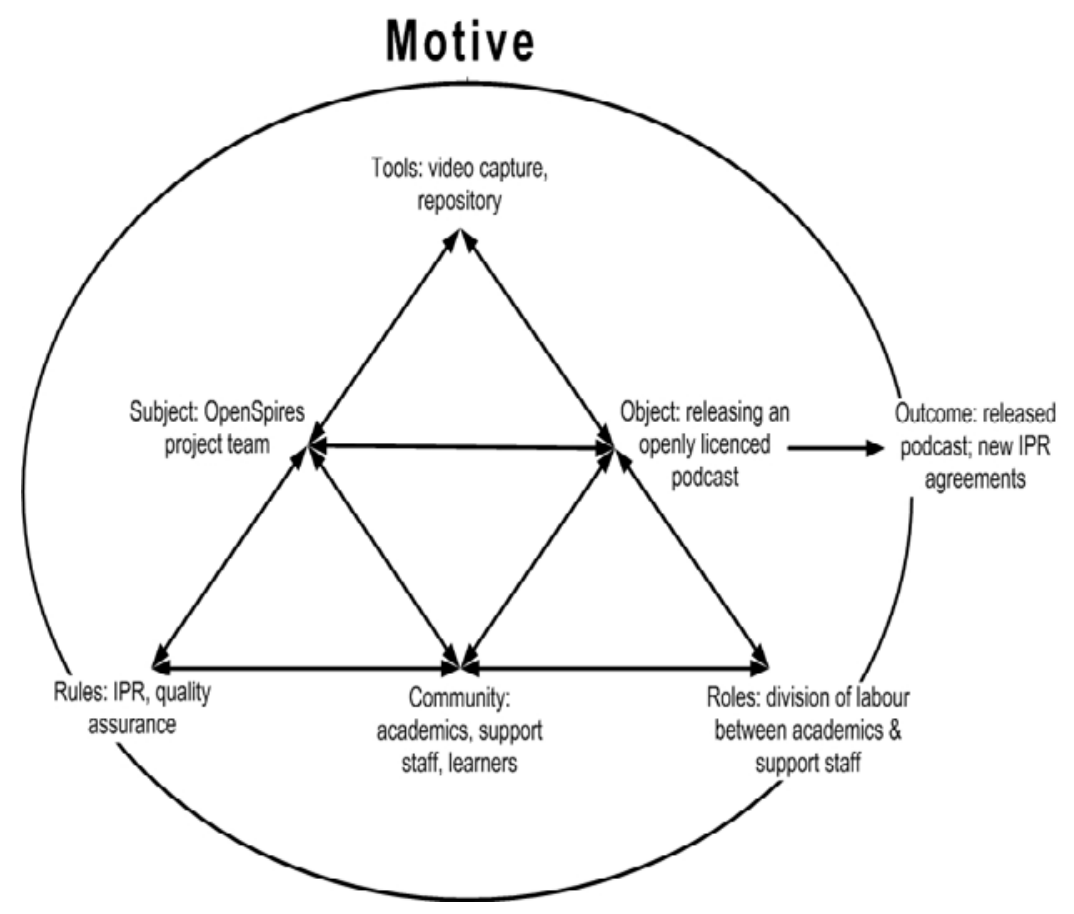

Figure 2. An activity triangle from the UKOER program, taking the OpenSpires Project (Robinson, 2010) as an example. The project team (subject) worked on open release of podcasts (objects) within an HE institutional context (community). The outcomes were released podcasts and new IPR agreements. The team used video capture and repository technologies (tools) to create and release OER.

Motives determine the direction of the activity and uphold higher-level values (Leontiev, 2005) or perspectives (Foot, 2002). There may be multiple motives within the system as subjects negotiate the relationship of their motives with the emergent motives of the community. Such differing motives give rise to tensions in the activity system (Nardi, 2005), which drive innovation and change in the system (Engeström, 2005). The tensions may lie within a single component of the system, for example, the marketing value of publicising OER through Twitter versus the time needed to do so effectively. Alternatively, tensions may be between components, for example, the educational benefit of implementing a situative pedagogy versus the legal risk to the institution of hosting the required open collaborative platform. A third form of tension arises when the guiding motives come into conflict, for example, when ideals of open access to knowledge oppose existing institutional commercial practice. The UKOER project teams (subjects), whether individual, subject-based, or institutional, all operated within the context of higher education institutions (community), and motives often came into conflict.

The method is explorative in its application of an activity framework across a collection of 29 diverse project activities. Using an organisational framework loosely derived from an activity system has allowed us to view the UKOER projects in a coherent way through an analytic lens that foregrounds tensions and motives while recognising the complex relationships within the program. Other outcomes of the analysis, pertaining to community and trust, are the subject of a companion paper (Littlejohn, Falconer, McGill, \& Beetham, 2014). 


\section{Results and discussion}

\section{Overarching motives in the release of OER}

Our clustering of aims and anticipated benefits suggested five candidate areas of high-level motives associated with the UKOER program:

- building individuals', institutions’ or subject community’s reputation, exemplified by the Open Content Employability and OpenStaffs projects, which aimed to use OER as a mechanism to showcase institutions and attract potential students (Morris, 2010; Stiles \& Hall, 2010)

- improving efficiency, cost and quality of resource production, exemplified by the Unicycle project, which examined the resource release strategy from creation through to reuse (Thomson, 2010)

- $\quad$ opening access to knowledge, exemplified by the ChemistryFM project, which explicitly adopted a "teaching in public" approach (Winn, 2010, p. 3)

- $\quad$ enhancing pedagogy through the creation and reuse of OER, aligned with opening access to knowledge and exemplified by the Java Bread-Board project which adopted an open-source community model to developing the tool-set (Crispin-Bailey, 2010)

- $\quad$ building technological momentum (and being funded to do so), evidenced in the JISC call itself (JISC, 2009b).

These categories are summarised in Table 1.

Table 1

Summary of categories of motives for OER release evident in the UKOER projects

\begin{tabular}{|c|c|c|c|c|c|}
\hline & $\begin{array}{l}\text { Reputation } \\
\text { building }\end{array}$ & $\begin{array}{l}\text { Efficiency/ } \\
\text { income generation }\end{array}$ & $\begin{array}{l}\text { Open access to } \\
\text { knowledge }\end{array}$ & $\begin{array}{l}\text { Enhancing } \\
\text { pedagogy }\end{array}$ & $\begin{array}{l}\text { Technological } \\
\text { momentum }\end{array}$ \\
\hline $\begin{array}{l}\text { Some } \\
\text { characteristics } \\
\text { of OER release } \\
\text { with the motive }\end{array}$ & $\begin{array}{l}\text { Potential } \\
\text { students as users } \\
\text { Unitary } \\
\text { resources that } \\
\text { cannot be } \\
\text { disaggregated to } \\
\text { broadcast } \\
\text { content (e.g., } \\
\text { podcasts, } \\
\text { videos) } \\
\text { Social software } \\
\text { to advertise } \\
\text { resources }\end{array}$ & $\begin{array}{l}\text { Teachers as users } \\
\text { Resources that } \\
\text { can be } \\
\text { disaggregated, } \\
\text { with examples of } \\
\text { pedagogic use }\end{array}$ & $\begin{array}{l}\text { Coherent body } \\
\text { of resources, } \\
\text { often with } \\
\text { pedagogic } \\
\text { wrapper } \\
\text { Social software } \\
\text { to advertise } \\
\text { resources }\end{array}$ & 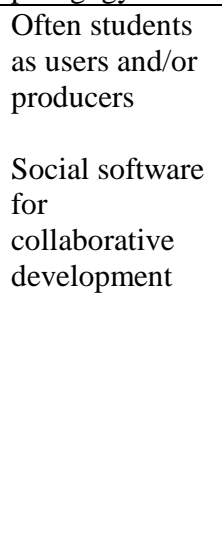 & $\begin{array}{l}\text { Further } \\
\text { development of } \\
\text { existing } \\
\text { infrastructure } \\
\text { and expertise }\end{array}$ \\
\hline $\begin{array}{l}\text { Common values } \\
\text { underlying } \\
\text { motive }\end{array}$ & \multicolumn{2}{|c|}{$\begin{array}{l}\text { A marketisation model of higher } \\
\text { education }\end{array}$} & \multicolumn{2}{|c|}{$\begin{array}{l}\text { Belief in open access to knowledge } \\
\text { and collective intelligence }\end{array}$} & $\begin{array}{l}\text { To capitalise on } \\
\text { existing } \\
\text { investment }\end{array}$ \\
\hline $\begin{array}{l}\text { Existing } \\
\text { literature that } \\
\text { identifies the } \\
\text { motive }\end{array}$ & $\begin{array}{l}\text { Atkins et al. } \\
\text { (2007); } \\
\text { Downes (2007); } \\
\text { OECD (2007) }\end{array}$ & $\begin{array}{l}\text { Atkins et al. } \\
\text { (2007); } \\
\text { Downes (2007); } \\
\text { OECD (2007); } \\
\text { Willems \& Bossu } \\
\text { (2012) }\end{array}$ & $\begin{array}{l}\text { Atkins et al. } \\
\text { (2007); } \\
\text { Downes (2007); } \\
\text { OECD (2007); } \\
\text { Bossu \& Tynan } \\
\text { (2011) }\end{array}$ & $\begin{array}{l}\text { Atkins et al. } \\
\text { (2007); } \\
\text { Beetham et al. } \\
\text { (2011); } \\
\text { Kernohan } \\
\text { (2011); } \\
\text { Stagg (2014) }\end{array}$ & $\begin{array}{l}\text { Not previously } \\
\text { identified }\end{array}$ \\
\hline
\end{tabular}

Table 2 illustrates in more detail the clustering and the overarching motives suggested. The motives described in the literature mapped easily to this classification, as shown in Table 3. Other motives identified in the literature may be considered as an interaction between one of these five and a specific context. Sustaining minority disciplines, for example, identified in McGill et al. (2008), become the particular form of an open access to knowledge motive held by the community of the minority discipline. 
Table 2

Mapping of benefits against five high level motives identified. The table clusters statements of anticipated benefits drawn from the UKOER program into five types of motive.

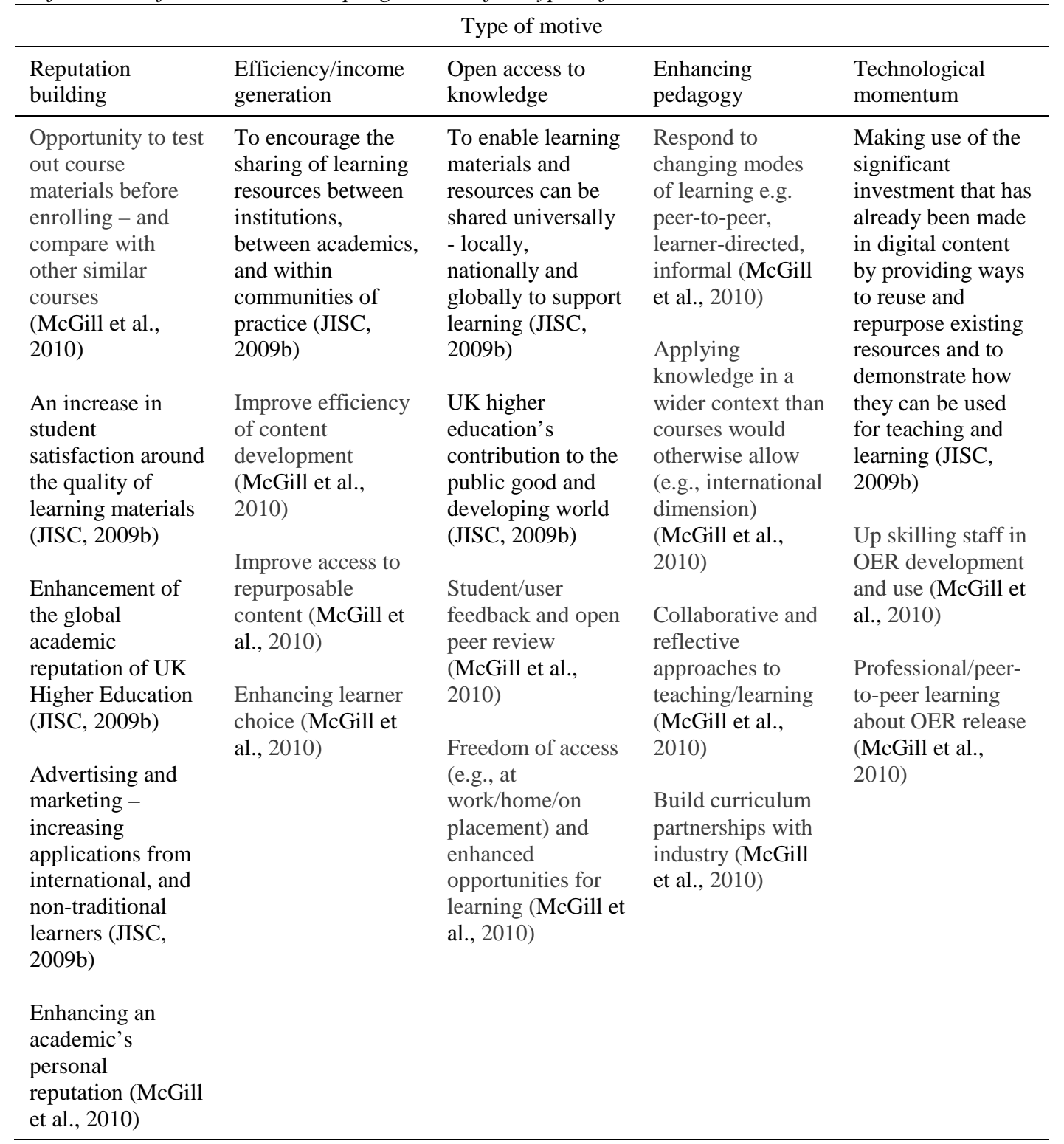


Table 3

Test that motives identified in the literature can be mapped against the five types of motive identified in the UKOER program

\begin{tabular}{|c|c|c|c|c|}
\hline \multicolumn{5}{|c|}{ Type of motive } \\
\hline $\begin{array}{l}\text { Reputation } \\
\text { building }\end{array}$ & $\begin{array}{l}\text { Efficiency/income } \\
\text { generation }\end{array}$ & $\begin{array}{l}\text { Open access to } \\
\text { knowledge }\end{array}$ & $\begin{array}{l}\text { Enhancing } \\
\text { pedagogy }\end{array}$ & $\begin{array}{l}\text { Technological } \\
\text { momentum }\end{array}$ \\
\hline $\begin{array}{l}\text { Improve publicity } \\
\text { to gain the first- } \\
\text { mover advantage } \\
\text { (OECD, 2007) } \\
\text { It is good for the } \\
\text { institution's public } \\
\text { relations to have } \\
\text { an OER project as } \\
\text { a showcase for } \\
\text { attracting new } \\
\text { students (OECD, } \\
\text { 2007) }\end{array}$ & $\begin{array}{l}\text { Implement cost } \\
\text { recovery models as } \\
\text { universities } \\
\text { experience } \\
\text { increased } \\
\text { competition } \\
\text { (OECD, 2007) } \\
\text { Reduce teaching } \\
\text { preparation time } \\
\text { (Willems \& Bossu, } \\
\text { 2012) } \\
\text { Increase efficiency } \\
\text { of content } \\
\text { development (OER } \\
\text { Africa, 2016) } \\
\text { Reduce cost of } \\
\text { publishing and } \\
\text { ownership } \\
\text { (Downes, 2007) }\end{array}$ & $\begin{array}{l}\text { The world's } \\
\text { knowledge is } \\
\text { viewed as a public } \\
\text { good (Atkins et al., } \\
\text { 2007) } \\
\text { Provide learners } \\
\text { with flexibility to } \\
\text { study anywhere } \\
\text { and anytime; at no } \\
\text { or low costs } \\
\text { (Kanwar et al., } \\
\text { 2010) } \\
\text { Promote open } \\
\text { access as an } \\
\text { international norm } \\
\text { (Cape Town Open } \\
\text { Declaration) } \\
\text { Promoting } \\
\text { intellectual } \\
\text { freedom (Downes, } \\
\text { 2007) }\end{array}$ & $\begin{array}{l}\text { They can bridge } \\
\text { the gap between } \\
\text { non-formal, } \\
\text { informal and } \\
\text { formal learning } \\
\text { (OECD, 2007) } \\
\text { Develop capacity } \\
\text { as active } \\
\text { participants rather } \\
\text { than passive } \\
\text { consumers (OER } \\
\text { Africa, 2016) } \\
\text { Act as a catalyst } \\
\text { for learner- } \\
\text { centered } \\
\text { pedagogy (Bossu } \\
\text { et al., 2012) } \\
\text { Students become } \\
\text { involved in the } \\
\text { discovery, use, } \\
\text { and reuse of OER } \\
\text { to support active } \\
\text { learning (Stagg, } \\
\text { 2014) }\end{array}$ & $\begin{array}{l}\text { The technological } \\
\text { and economic } \\
\text { drivers include } \\
\text { improved, less } \\
\text { costly and more } \\
\text { user-friendly } \\
\text { information } \\
\text { technology } \\
\text { infrastructure (such } \\
\text { as broadband), } \\
\text { hardware and } \\
\text { software (OECD, } \\
\text { 2007) }\end{array}$ \\
\hline
\end{tabular}

Of the five areas, the first three are well recognised and discussed, for example, in Downes (2007), OECD (2007), Atkins et al. (2007), and Bossu et al. (2014). We view our fourth category, enhancing pedagogy, as fundamentally different to that of producing high quality materials efficiently or cost effectively, in that it is underpinned by altruistic positions rather than a business model approach. It puts its emphasis on the value of the OER development process, rather than on the value of the OER content produced. Enhancing pedagogy was singled out as a motive by Atkins et al. (2007) but has been less widely recognised generally until recently. However, accumulating evidence from OER release initiatives, including the UKOER program, has highlighted the importance of changes in curriculum development practices (Beetham, McGill, Falconer, \& Littlejohn, 2011; Bossu et al., 2012; Kernohan, 2011; Stagg, 2014). The belief that the new practices improve pedagogy is, ultimately, founded on a commitment to open access to knowledge and to a philosophy of collective intelligence. A key motive for projects such as ChemistryFM and Open Exeter has been the potential for radical transformation of higher education (McGill et al., 2010).

Examination of these four motives suggests that they fall into two groups of two. Each group shares a common value, as shown in Table 1. The first group (reputation building, efficiency) share a marketisation model of higher education, based on cost-benefit analysis. The second group (enhancing pedagogy, open access to knowledge) repudiate marketisation as an appropriate model for higher education and are committed instead to a value of "academic commons" (Bollier, 2002).

The fifth motive, technological momentum, has not previously been identified explicitly as a motive underpinning OER release, although there is evidence in the literature that it may be tacitly held (e.g., Bossu et al., 2014; OECD, 2007). Technological momentum is the theory that as a technology develops, interests invested in the technology come into play and determine the direction in which society develops (Hughes, 1994). There is evidence in the UKOER program and OECD (2007) of vested interest at work to broaden the applications of technologies. Technological momentum is exemplified by statements such as, "The 
benefits of OER release include making use of the significant investment that has already been made in digital content” (JISC, 2009b, p. 3).

The motives we have identified are not necessarily independent and exclusive. It is entirely possible for projects to have several motives at once. This is obvious and is sometimes easy when the motives are based on the same common value. Thus an institution might, uncontroversially, be aiming to improve its reputation through efficient production of high quality didactic teaching materials (e.g., OpenSpires: Robinson, 2010). It becomes more difficult, but certainly possible at least in the short term, when the motives are based on fundamentally different values. For example, the individual-funded ChemistryFM project arose from a commitment to an academic commons philosophy but institutional buy-in was secured on the basis of reputation building (Winn, 2010).

Such multiple motives become apparent as tensions within and between components of the activity system - between the hidden or implicit motives not stated openly, and communities, rules and tools.

\section{Examples of tensions in activities}

The object of collaborative activity in the UKOER projects was releasing specific OER. This object interacted with the community environment along three different axes:

(1) Who does the initial development? Three models were evident - development by academics, development by central services, and development by students - often as part of project work.

(2) Who is the main intended audience? Envisaged audiences ranged from other teaching staff who will reuse the materials in new contexts, through students within the originating institution, to potential students and informal lifelong learners among the general public.

(3) Who, if anyone, will develop the materials further? A spectrum was evident from materials whose integrity was intended to be preserved - they can easily be reused but not repurposed - to those where ongoing development by the user community was explicitly solicited and functionality for doing so provided.

Although there was no direct correlation between motives and the pedagogic type of resource released, consideration of project positioning on these three axes may reveal motives. Thus, for example, release of unitary resources that could not be disaggregated but would broadcast content in a traditional didactic approach (such as podcast videos) and could not be developed or repurposed appears typically associated with a motive to extend reputation (e.g., OpenSpires: Robinson, 2010; MMTV: Stannard, 2010). This is in contrast to projects motivated to encourage collaborative pedagogic approaches; revealed, for example, by openSpace, which comprised a range of resources that could be further developed by students, associated with online discussions (di Savoia, 2010). Projects motivated to improve efficiency (e.g., brOME) tended to release aggregated resources including self-study assignments, open source software and collections of multiple choice questions, that could be disaggregated by teachers for use elsewhere (Van Hoorebeek, 2010).

Motives were revealed in projects' choice of tools for hosting and user interface. Generally, in choosing tools, motives of efficiency and technological momentum underlay the observation that projects tended to stick with technologies with which they were familiar and had in place (CETIS, 2010).

In deciding which hosting solution to use, projects considered issues such as updating, versioning, tracking and management, preservation and archiving. The JISC requirement that projects deposit their OER within JorumOpen (http://www.jorum.ac.uk/) contradicted the demands of projects motivated by reputation for branding and quality control. In most cases projects preferred to use their own institutional or community repositories in order to retain control of versioning and branding. This ensured that a single authoritative version existed for updating or any necessary takedown, and they used syndication to support discoverability through more accessible sources.

Evidencing technological momentum, many projects capitalised on the increasing development of institutional research repositories for learning and teaching resources. However, while the existence of an institutional repository might be a technological driver for open content release, it did not always support reputation, efficiency and pedagogic enhancement motives. Adoption of institutional research repositories 
for OER often presented problems, such as poor management of complex learning objects or poor integration with other institutional technologies (Morris, 2010).

Projects that wished to adopt more open practices, such as collaboration across institutional boundaries for pedagogic enhancement, or opening access to social constructivist or situative teaching approaches to learners outside their institutions, often found encountered problems. They found themselves in conflict with an institution concerned for its reputation and unwilling to host resources the content of which were not under local control (Crispin-Bailey, 2010; Stannard, 2010). Thus, they betrayed tension between the motives of the educators in the project team and the institution or community within which the project was situated.

The rules that are most likely to influence OER release are those surrounding disciplinary ways of working, intellectual property rights (IPR), and institutional quality processes. Subject disciplines that already have a tradition of sharing teaching resources across institutional boundaries are more likely to regard openness favourably and integrate it into their practice. However, IPR issues around open licensing caused tension even where publicly visible peer review and critique is an established practice. For example, the openSpace professional writing course was founded on industry expectations of collaboration. Yet openSpace found that it had to retain a non-commercial use only clause in their licence, and could not release resources fully openly, since tutor-authors' commercial earning power could be damaged by a perception that they were giving their work away for free (di Savoia, 2010).

More generally, tensions around IPR rules were significant. On the UKOER program all projects (individual, community, and institutional) were working within an institutional IPR framework. They demonstrated the falsity of a traditional perception that IPR rules relate more strongly to institutions than to individuals, and that releasing unlicensed resources as an individual, or within a subject consortium, is relatively safe (Hoosen \& Butcher, 2012). Projects experienced issues in relation to institutional branding and reputation. While some projects adopted a light-touch approach to adhering to institutional IPR rules, others were risk-averse, particularly when based in institutions where merely asking the question about open licensing led to increased scrutiny of project activities, and barriers being placed in the way of project outcomes (McGill et al., 2010). The discrepancy between the current normal practice of limited adherence to IPR rules when resources are not openly available, and strict application of IPR rules when resources are open, means that projects may find IPR rules are a major inhibitor of OER release.

Another tension related to attributing copyright. By far the most time-consuming factor for projects releasing existing content as OER, was identifying provenance and attribution. Frequently, the effort involved in clearing rights for existing materials was not viable, especially where resources had been created from multiple sources and in multiple media (Thomson, 2010). Instead of repurposing and reusing existing resources, many projects argued that it was significantly cheaper to design new content with copyright clearance. The differential between the time to attribute copyright compared with the time to create a new resource may push future projects towards production of new resources rather than reuse of existing ones. This would negate the efficiency motive - although this differential may decrease if OER release becomes more mainstream and resources are properly licensed from the outset (Chin \& Madden, 2010; Van Hoorebeek, 2010).

\section{Conclusion}

We have analysed the experience of the UKOER pilot projects, using a framework loosely based on activity theory, to draw out implicit motives and inherent tensions among OER release projects. We have mapped these successfully against our initial list of candidate motives. This exercise revealed the multiplicity of motives held by many projects but often not stated openly. This multiplicity might arise for a single individual - for example, educators who believe in open collaborative teaching but need also to preserve commercial income - or between project teams and the institution within which they are situated. Such multiple motives most frequently came into conflict when they were between projects holding altruistic "academic commons" (Bollier, 2002) values and institutions upholding a marketization model of higher education and concerned for their reputation.

Through our analysis, some fundamental tensions have become apparent that will need to be resolved if the purposes of OER release are to be realised. 
Motives of reputation and efficiency were reflected in the forms of OER released. Yet the life course of the UKOER projects was not long enough to assess uptake of the resources released or whether the forms were appropriate. For example, where reputation was a motive, many of the resources could not be disaggregated and were designed for direct use by students, or reuse by teachers, but not for repurposing. Does this, in itself, reduce the likelihood of their being adopted and having an extended life, and thus limit the reputational benefits gained?

Differing motives frequently brought rule systems into conflict, and tensions were common, often evidenced by institutions perceiving project activities as a risk to their reputation and pushing for more control in the face of novel ways of working. Such actions may call into question the claims of the institutions that they are motivated by altruism and opening up wider educational opportunities. They certainly inhibit innovation and may ultimately limit the potential efficiency gains of OER as well as curtailing the ambitions of educators motivated to enhance pedagogy or open access to knowledge. In the UKOER program, individual-funded projects were more likely to show evidence of academic commons values, while institutional projects were more likely to adhere to a marketisation model of higher education.

Reputation building was a frequent motive among both individual and institutional projects. Yet it is one that imposes fundamental limits on adoption of OER unless there is a radical shift in attitudes to reuse and repurposing. There is an engrained cultural idea that those who originate materials are more worthy of credit than those who reuse or repurpose them. This is revealed by institutional concerns to assure quality and reluctance to take responsibility for contributions from outsiders, and by the demand for recognition schemes to incentivise individuals to release materials. Indeed, the whole purpose of IPR and Creative Commons licensing is to ensure that originators of materials get recognition. Ultimately, though, a reputation motive is at odds with other motives in the OER activity system; institutions and individuals want to originate and disseminate their work rather than "merely" reusing or repurposing that of others. Yet among the main benefits of OER are said to be the efficiency of reuse and repurposing, and the enhanced quality resulting from community development. Attaching reputation to the originators of materials, but not to reusers or repurposers, will limit achievement of these efficiency or pedagogic benefits. Conversely, if we recognise that reputation building is a strong motive, then a culture of recognition for reuse and repurposing needs to be developed if efficiency or pedagogic benefits are to be realised.

This limits imposed by a reputation-building motive are exacerbated at present as higher education institutions are encouraged to become increasingly competitive, elevating the importance of brand recognition. The consequence is a move away from risk-taking, towards a demand for predictable quality outcomes. This discourages innovation unless direct benefits can be proven in terms of new markets, student numbers, or shared costs of development and teaching. The benefits of OER in terms of institutional showcasing and attracting potential students, may prove attractive to institutional managers and gain institutional support for OER, but unless culture changes, they place inherent limitations on efficiency gains and the adoption of more open practices which are ultimately founded on a commitment to academic commons.

\section{Acknowledgements}

It gives us pleasure to acknowledge the support of the UK Joint Information Systems Committee and Higher Education Academy, who funded the UKOER projects upon which this paper is based.

\section{References}

Atkins, D. E., Seely Brown, J., \& Hammond, A. L. (2007). A review of the open educational resources (OER) movement: Achievements, challenges, and new opportunities (Report to the William and Flora Hewlitt Foundation). Retrieved from http://www.hewlett.org/uploads/files/Hewlett_OER report.pdf

Barroso, J. M. (2012, January). Growth and jobs: Next steps. Presentation to the informal European Council. Retrieved from http://ec.europa.eu/europe2020/pdf/cm012012_barroso_en.pdf 
Beetham, H., McGill, L., Falconer, I., \& Littlejohn, A. (2011). Open practices briefing paper. Retrieved from https://oersynth.pbworks.com/w/page/51668352/OpenPracticesBriefing

Bollier, D. (2002). The enclosure of the academic commons. Academe, 88(5), 18-22. Retrieved from http://dx.doi.org/10.2307/40252215

Bossu, C., Brown, M., \& Bull, D. (2014). Adoption, use and management of open educational resources to enhance teaching and learning in Australia (Final Report). Armidale: University of New England. Retrieved from http://www.olt.gov.au/system/files/resources/CG10_1687_Bossu_Report_2014.pdf

Bossu, C., Bull, D., \& Brown, M. (2012). Opening up Down Under: The role of open educational resources in promoting social inclusion in Australia. Distance Education, 33, 151-164. http://dx.doi.org/10.1080/01587919.2012.692050

Bossu, C., \& Tynan, B. (2011). OERs: New media on the learning landscape. On the Horizon, 19(4), 259-267. http://dx.doi.org/10.1108/10748121111179385

Cape Town Declaration. (2008). Read the Declaration. Retrieved from http://www.capetowndeclaration.org/read-the-declaration

Center for Activity Theory and Developmental Work Research. (2004). The activity system. Retrieved from http://www.edu.helsinki.fi/activity/pages/chatanddwr/activitysystem/

CETIS. (2010). UKOER pilot phase synthesis. Retrieved from http://wiki.cetis.ac.uk/ukoer_synthesis

Chin, P., \& Madden, T. (2010). Skills for Scientists project (Final Report). Retrieved from http://www.heacademy.ac.uk/assets/documents/oer/Skills for_scientists final report_completed.pdf

Commonwealth of Learning. (2014). UNESCO-COL chairs. Retrieved from http://www.col.org/about/unesco-col-chairs/unesco-col-chairs

Cooper, N., Lockyer, L., \& Brown, I. (2013). Developing multiliteracies in a technology-mediated environment. Educational Media International, 50 (2), 93-107. http://dx.doi.org/10.1080/09523987.2013.795350

Crispin-Bailey, C. (2010). Java Bread-Board project (Final Report). Retrieved from http://www.heacademy.ac.uk/assets/York/documents/ourwork/oer/OER_1_York_final_report.pdf

DEHub. (2012). DEHub. Retrieved from http://wikieducator.org/DEHub

di Savoia, A. (2010). Open Space project (Final Report). Retrieved from http://www.heacademy.ac.uk/assets/York/documents/ourwork/oer/OER_final_report_openSpaceFinal May2010v2FALMOUTH.doc

Dmochowski-Lipski, P. (2014, February). Opening of educational resources: Poland's actions and perspective. Presentation to the European Parliament, Brussels. Retrieved from http://oerpolicy.eu/wpcontent/uploads/2014/02/PL_OpenResourcesEParliamentFebruary182014.pdf

Downes, S. (2007). Models for sustainable open educational resources. Interdisciplinary Journal of Knowledge and Learning Objects, 3, 29-44. Retrieved from http://www.ijello.org/Volume3/IJKLOv3p029-044Downes.pdf

Edwards, A. (2010). Being an expert professional practitioner: The relational turn in expertise. Dordrecht: Springer.

Engeström, Y. (1987). Learning by expanding. Helsinki: Orienta-konsultit. Retrieved from http://lchc.ucsd.edu/mca/Paper/Engestrom/expanding/toc.htm

Engeström, Y. (2005). Knotworking to create collaborative intentionality capital in fluid organizational fields. In M. M. Beyerlein, S. T. Beyerlein, \& F. A. Kennedy (Eds.), Collaborative capital: Creating intangible value (pp. 307-336). Amsterdam: Elsevier.

Europa. (2009). EU cooperation in education and training 2020 (ET 2020). Retrieved from http://europa.eu/legislation_summaries/education_training_youth/general_framework/ef0016_en.htm

European Commission. (2013). Europe 2020. Retrieved from http://ec.europa.eu/europe2020/index en.htm

Foot, K. A. (2002). Pursuing an evolving object: A case study in object formation and identification. Mind, Culture, and Activity, 9, 132-149. http://dx.doi.org/10.1207/S15327884MCA0902_04

Glaser, B., \& Strauss, A. (1967). The discovery of grounded theory: Strategies for qualitative research. Chicago, IL: Aldine.

Hoosen, S., \& Butcher, N. (2012). Experiences of developing OER-amenable policies. In J. Glennie, K. Harley, N. Butcher, \& T. van Wyk (Eds.), Open educational resources and change in higher education: Reflections from practice (pp. 217-240). Vancouver: Commonwealth of Learning. Retrieved from https://oerknowledgecloud.org/sites/oerknowledgecloud.org/files/pub_PS_OER_web.pdf 
Hughes, T. (1994). Technological momentum. In M. R. Smith \& L. Marx (Eds.), Does technology drive history? The dilemma of technological determinism (pp. 101-113). Cambridge, MA: MIT Press.

Joint Information Systems Committee. (2009a). Briefing paper on open educational resources. Retrieved from http://www.jisc.ac.uk/media/documents/funding/2008/12/oerbriefingv4.doc

Joint Information Systems Committee. (2009b). HEFCE/Academy/JISC open educational resources programme: Call for projects. Retrieved from http://www.jisc.ac.uk/media/documents/funding/2008/12/oercall.doc

Kanwar, A., Kodhandaraman, B., \& Umar, A. (2010). Toward sustainable open education resources: a perspective from the global south. American Journal of Distance Education, 24(2), 65-80. http://dx.doi.org/10.1080/08923641003696588

Kernohan, D. (2011, February 8). For a few dollars more? OER, reuse and value [Blog post]. Followers of the Apocalypse. Retrieved from

http://followersoftheapocalyp.se/for-a-few-dollars-more-oer-reuse-and-value/

Lane, A., \& McAndrew, P. (2010). Are open educational resources systematic or systemic change agents for teaching practice? British Journal of Educational Technology, 41, 952-962. http://dx.doi.org/10.1111/j.1467-8535.2010.01119.x

Leontiev, A. N. (1981). The problem of activity in psychology. In J. V. Wertsch (Ed.), The concept of activity in Soviet psychology, (pp. 37-73). Armonk, NY: M. E. Sharpe.

Leontiev, D. A. (2005). Three facets of meaning. Journal of Russian \& East European Psychology. 43, 45-72. http://dx.doi.org/10.1080/10610405.2005.11059270

Littlejohn, A., Falconer, I., McGill, L., \& Beetham, H. (2014). Open networks and bounded communities: Tensions inherent in releasing open educational resources. In A. Littlejohn \& C. Pegler (Eds.), Reusing open resources: Learning in open networks for work, life and education (pp. 57-69). Abingdon: Routledge.

Livingston-Vale, K. \& Long, P. (2003). Models for open learning. In A. Littlejohn (Ed.), Reusing online resources: A sustainable approach to elearning (pp. 60-74). London: Kogan Page.

McGill, L., Beetham, H., Falconer, I., \& Littlejohn, A. (2010). JISC/HE Academy OER programme: Pilot phase synthesis and evaluation report (Final Report). Retrieved from https://OERynth.pbworks.com/w/page/29688444/Pilot\%20Phase\%20Synthesis\%20and\%20Evaluatio n\%20Report

McGill, L., Currier, S., Duncan, C., \& Douglas, P. (2008). Good intentions: Improving the evidence base in support of sharing learning materials (Final Report). Retrieved from http://ierepository.jisc.ac.uk/265/1/goodintentionspublic.pdf

McGill, L., Falconer, I., Dempster, J.A., Littlejohn, A., \& Beetham, H. (2013). Journeys to Open Educational Practice: UKOER/SCORE Review (Final Report). Retrieved from https://oersynth.pbworks.com/w/page/60338879/HEFCE-OER-Review-Final-Report

Morris, D. (2010). OCEP project (Final Report). Retrieved from http://www.jisc.ac.uk/media/documents/programmes/oer/ocepfinalcomplete_web.pdf

Nardi, B. A. (2005). Objects of desire: Power and passion in collaborative activity. Mind, Culture, and Activity, 12, 37-51. http://dx.doi.org/10.1207/s15327884mca1201_4

New Zealand Government. (2010). New Zealand Government open access and licensing framework (NZGOAL). Retrieved from http://ict.govt.nz/guidance-and-resources/information-and-data/nzgoal

OER Africa. (2016). OER Africa. Retrieved from http://www.oerafrica.org/

OPAL. (2016). Open Educational Quality Initiative (OPAL). Retrieved from http://www.open.ac.uk/iet/main/research-innovation/research-projects/open-educational-qualityinitiative-opal

Organisation for Economic Co-operation and Development. (2007). Giving knowledge for free: The emergence of open educational resources. Retrieved from http://www.oecd.org/document/41/0,3746,en_2649_35845581_38659497_1_1_1_1,00.html

Panke, S. (2011). An expert survey on the barriers and enablers of open educational practices. eLearning Papers, 23. Retrieved from https://oerknowledgecloud.org/content/expert-survey-barriers-andenablers-open-educational-practices

RCC2012. (2012). University of Canberra/RCC2012. Retrieved from https://en.wikiversity.org/wiki/University_of_Canberra/RCC2012

Robinson, P. (2010). OpenSpires project (Final Report). Retrieved from http://openspires.oucs.ox.ac.uk/report/index.html

Rossini, C., Sebriam, D., Gonsales, P., \& Santana, B. (2011, October 3). Decree on open educational resources [Blog post]. REA-Brasil. Retrieved from 
https://reabrasil.wordpress.com/2011/10/03/decreto-sobre-rea-em-vigor-em-sao-paulo/

Stagg, A. (2014). OER adoption: A continuum for practice. RUSC: Universities and Knowledge Society Journal, 11(3), 151-64. http://dx.doi.org/http://dx.doi.org/10.7238/rusc.v11i3.2102

Stannard, R. (2010). MMTV project (Final Report). Retrieved from http://www.heacademy.ac.uk/assets/York/documents/ourwork/oer/OER_1_Westminster_final_report. pdf

Stiles, M., \& Hall, S. (2010). OpenStaffs project (Final Report). Retrieved from http://www.jisc.ac.uk/media/documents/programmes/oer/openstaffs_final_april.doc

Thomson, S. 2010. Unicycle project (Final Report). Retrieved from http://www.jisc.ac.uk/media/documents/programmes/oer/unicycle_final_report.doc

UNESCO. (2012). Open educational resources. Retrieved from http://www.unesco.org/new/en/communication-and-information/access-to-knowledge/openeducational-resources/

Van Hoorebeek, M. (2010). brOME project (Final Report). Retrieved from http://www.heacademy.ac.uk/assets/York/documents/ourwork/oer/Bradford_final_rep.docx

Willems, J., \& Bossu, C. (2012). Equity considerations for open educational resources in the glocalization of education. Distance Education, 33, 185-199. http://dx.doi.org/10.1080/01587919.2012.692051

Winn, J. (2010). ChemistryFM project (Final Report). Retrieved from http://www.heacademy.ac.uk/assets/documents/oer/OER_1_Lincoln_Final_Report.pdf

Yuan, L., MacNeil, S., \& Kraan, W. (2008). Open Educational Resources - Opportunities and Challenges for Higher Education (Report). Retrieved from http://wiki.cetis.ac.uk/images/6/6d/OER_Briefing_Paper_CETIS_without_recommendations_with_co ver_page.pdf

Corresponding author: Isobel Falconer, ijf3@st-andrews.ac.uk

Australasian Journal of Educational Technology (c) 2016.

Please cite as: Falconer, I., Littlejohn, A., McGill, L., \& Beetham, H. (2016). Motives and tensions in the release of open educational resources: The UKOER program. Australasian Journal of Educational Technology, 32(4), 92-105. 